\title{
TITLE:
}

\section{ASCIDIANS FROM THE PALAO ISLANDS. II}

$\operatorname{AUTHOR}(\mathrm{S})$ :

Tokioka, Takasi

\section{CITATION:}

Tokioka, Takasi. ASCIDIANS FROM THE PALAO ISLANDS. II.

PUBLICATIONS OF THE SETO MARINE BIOLOGICAL LABORATORY 1955, 5(1): 43-57

ISSUE DATE:

1955-12-20

URL:

http://hdl.handle.net/2433/174536

RIGHT: 


\title{
ASCIDIANS FROM THE PALAO ISLANDS. II $^{13}$
}

\author{
TAKASI TOKIOKA
}

Seto Marine Biological Laboratory, Sirahama

With Plates $I-V I$ and 4 Text-figures

Examining the remaining specimens of the ascidians collected at the Palao Islands, more nine species were discriminated. They are :-

1. Aplidium lobatum SavignY

2. Didemnum moseleyi (HERDMAN)

3. Didemnum candidum (SAvigny)

4. Didemnum ternatanum (GotTSCHALDT)

5. Eudistoma viridis n. sp.

6. Eudistoma rigida $\mathrm{n}$. sp.

7. Distaplia mikropnoa (SLUITER)

8. Polycarpa aurata (QUOY et GAIMARD)

9. Pyura sp.

Among these species, two forms seem to be new to science. In the following, I propose to give descriptions on new species and also on others to certificate my identification.

\section{Aplidium lobatum SAvignY, 1816}

(Pl. I, Figs. 1-5)

Aplidium tremulum-SLuITER (1909): Siboga-Exped., LVI b, pp. 99-100.

Aplidium lobatum-VAN NAME (1945) : Bull. American Mus. Nat. Hist., Vol. 84, pp. 28-29, Fig. 3.

Many colonies attached to the sea-weeds. Colonies roughly globular in shape, usually ca. $12 \mathrm{~mm}$ in diameter and $5-10 \mathrm{~mm}$ in height, although larger ones may reach $22 \mathrm{~mm}$ in diameter. Colour in life brownish red, but fades to pale sandy in preservation in alcohol. A roundish common cloacal aperture is situated at the apex of the colony and about seven canals are issued radially from the cloacal aperture; about 10 zooids are arranged along each side of the respective canals with their atrial apertures facing towards the canal.

1) Contributions from the Seto Marine Biological Laboratory, No. 268.

Publ. Seto Mar. Biol. Lab., V (1), 1955. (Article 2) 
Test: The test is covered with muds along the radial canals and the intermediate zones between paired rows of zooids arranged along each side of respective canals. Thus, the test is exposed above zooids; the dorso-anterior part of the thorax of each zooid, just enclosing the area around the dorsal ganglion, shows a silvery glistening when alive. The test is soft gelatinous and contains fine sand grains within it; zooids are easily taken out of the test.

Zooid: Zooids up to $5 \mathrm{~mm}$ in length, thorax is slightly longer than abdomen and postabdomen taking both parts together.

Thorax: Branchial aperture distinctly 6-lobed; atrial languet rather short, the tip is simple to trifid. About 13 longitudinal muscles on each side of the thoracic mantle, being converged into a pair of ventral longitudinal muscles along the abdomen; besides large roundish vacuolar cells are scattered on the thoracic mantle. Stigmatal rows 7, stigmata up to ca. 13 in each row. Tentacles 18 including minute ones, dorsal languets short and displaced to the left side from the dorso-median line. Anus is bilobed and opens on the level of the 6th transverse vessel. Incubatory chamber is found near the anus on the right side and contains, for instance, 2 mature eggs in an examined zooid.

Abdomen: Stomach is situated near the middle of the abdomen and provided with 5 stout ridges. A pair of distinct coeca are found at the beginning portion of the rectum. Both hind stomach and mid-intestine are very distinct, the latter occupies the posterior end of the intestinal loop.

Postabdomen: Very short.

Remarks: This species is easily distinguishable from others by its characteristical shape of the colony. Zooids from the colonies in the present material resemble most closely those of the specimens from the West Indies (VAN NAmE, 1945).

\section{Didemnum (Didemnum) moseleyi (HERDMAN), 1886}

(P1. I, Figs. 6-9)

A small whitish colony, $15 \mathrm{~mm} \times 10 \mathrm{~mm}$ in extent and $1 \mathrm{~mm}$ in thickness, was found on a specimen of Polycarpa cryptocarpa collected on the reef of Gadaraku. Calcareous spicules are distributed throughout the test evenly and densely. They are usually about $36 \mu$ in diameter, although larger ones may be up to $53 \mu$; rays are acutely pointed distally and usually less than 15 in number on the equatorial plane. In some spicules, rays are more numerous, short and bluntly tipped. Zooids are arranged in irregular groups. Thorax ca. $400 \mu$ and abdomen $470 \mu$ in length, the latter is embedded firmly in the test. The outline of circum-intestinal gland is usually indistinct, although it assumes sometimes the appearance as shown in Figs. 8-9. Gonad not found in any examined zooids. 
Remarks: Rays of spicules on the equatorial plane are slightly more than in general colonies of Did. moseleyi. This feature alludes the possibility of the identity of the present specimen with Did. candidum. In general, the circum-intestinal gland is scarcely observable distinctly in Did. moseleyi. But it is fairly clear on a few zooids in the present colony. This feature lets me recall the resemblance between the present specimen and species of the subgenus Polysyncraton, although no trace of the atrial languet is found on any examined zooids. For these reasons, the present identification is considered rather to be of a provisional nature.

\section{Didemnum (Didemnum) candidum (SAvignY), 1816}

(P1. II, Figs. 10-17; Text-fig. 1)

Many colonies were found attached to the rock surface near the low water-mark in the canal of Geruherugaeru. They grow to a considerably large size; for instance, larger ones are $40 \mathrm{~mm} \times 50 \mathrm{~mm}$ to $35 \mathrm{~mm} \times 70 \mathrm{~mm}$ in extent. Thickness is usually ca. $1 \mathrm{~mm}$, but up to $2 \mathrm{~mm}$ at thickened parts or even to $4 \mathrm{~mm}$ in exceptional cases. Colour in life varies from pink to crimson, showing many intermediate grades of colouration such as dark pink, scarlet or red; this colouration fades easily to grayish or pale grayish brown in alcohol. Surface of colony nearly even or slightly elevated on respective zooids with each branchial aperture at the apex (Pl. II fig. 12). Common cloacal apertures are scattered here and there and their diameter is as large as that of the zooids. Calcareous spicules are distributed quite evenly and densely throughout the test, or slightly sparse in the middle layer. In many cases, spicules are very sparse in a small area surrounding each branchial aperture which is fringed with dense spicules, and the dark inner side of the colony is seen through this translucent spiculeless area. Thus, in life, a dark brownish ring encircles the white ring in which the branchial aperture is opened. Spicules are small, usually $20 \mu$ or thereabout in diameter and up to $29 \mu$ in maximum in examined colonies. Rays are short and very numerous, usually more than two dozens on the equatorial plane. In some colonies, the tips of rays seem to be pointed more acutely in the superficial layer than in inner or lower layers.

Zooid: Average distance between zooids $490-550 \mu$. Zooids vary considerably in size; they are usually about $1 \mathrm{~mm}$ in length, while they may be nearly $1.7 \mathrm{~mm}$ in some colonies. Thorax $450 \mu$ (contracted) to $730 \mu$ (large and expanded), abdomen 550-640 $\mu$; neck region may attain to a considerable length in some zooids. An ear-like thoracic organ at the postero-lateral side of the atrial aperture on each side. Eight to ten stigmata in each of 4 rows. The intestinal loop may be simple in zooids without gonads, but the rectum always curves remarkably in zooids with voluminous gonads. The stomach proper roundish in outline and rather short, while the hind stomach is very large. Anus situated on the level between the 3rd and the 4th stigmatal rows. 
Testicular follicle 1 or 2 in some larger zooids. The proximal part of the vas deferens coils $3 \frac{1}{2}$ to 7 times.

Larva: Embryos are found in the bottom layer. An examined embryo is $820 \mu$ in length and $680 \mu$ in width. Three cup-shaped attachment processes arranged linearly, four pairs of ectodermal ampullae are found at the base of the attachment processes.

Remarks: A considerable number of small colonies were found attached to the test of specimens of Polycarpa cryptocarpa collected on the reef of Gadaraku (Textfig. 1). They are less than $6 \mathrm{~mm} \times 6 \mathrm{~mm}$ in extent and the surface of the colony is slightly swollen up. A common cloacal aperture at the centre, the neighbouring areas

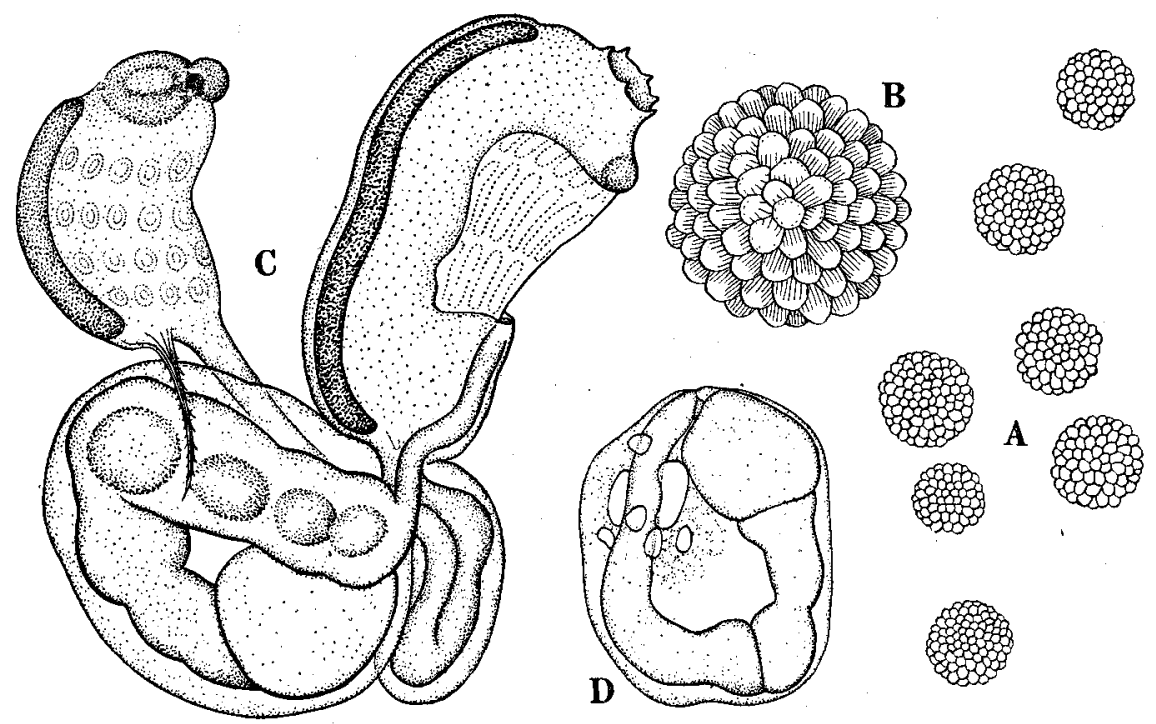

Fig. 1. Didemnum (Didemnum) candidum SAVIGNY. A-Calcareous spicules, $\times 440 ; B-A$ spicule, $\times 1200 ; C-$ Zooid with a developed bud, $\times 73$; D-Abdomen from right side, $\times 73$.

surrounding the cloacal aperture and some branchial apertures are purplish brown in colour, while the rest is whitish. Spicules $\pm 21 \mu$ in diameter, rays short and numerous; they are found merely in a thin superficial layer. The inner and lower layers of the colony are made with soft translucent tissue and rich in lacunae. Thorax $640 \mu$ in an expanded state and abdomen ca. $470 \mu$ in length. Retractile muscle distinct. Eight stigmata in each of 4 stigmatal rows, tentacles ca. 7 . Anus situated on the level of the 3rd transverse vessel. Gonads not yet developed. At the first sight of these specimens, I considered them as being youngs of the following species, because the distribution of spicules and the appearance of budding zooids (Fig. $1 \mathrm{C}$ ) are superficially very like D. ternatanum. However, the existence of distinct retractile 
muscle, quite absence of zoochlorella and fewer tentacles conflict with this identification. Probably these colonies are young ones of Did. candidum.

\section{Didemnum (Didemnum) ternatanum (GotTsChaLDT), 1897}

(Pl. III, Figs. 18-29)

Didemnoides ternatanum GotrschaldT, R. (1899): Synascidien von Ternate. Abh. Senckenberg. naturforsch. Gesell., Bd. XXIV, Hft. 1, pp. 648-649, Taf. XXXV fig. 1.

Didemnum ternatanum-VAN NAME (1918): U. S. Nat. Mus. Bull. 100, Vol. 1, Pt. 2, pp. 152-155, Figs. 104-106.

Many colonies attached to the leaves of Enhalus acoroides (L.f) STEUD near Iwayama Bay and a few ones attached to coral debris. They are roughly dome-shaped, up to $15 \mathrm{~mm}$ in diameter at the base and $15-18 \mathrm{~mm}$ in height. A roundish common cloacal aperture, about $1.5 \mathrm{~mm}$ in diameter, is opened at the apex of the dome and through which the green colouration of the inner-side of the colony can be seen distinctly. The surface of the cone is even and coloured brownish or grayish excepting the margin of the common cloacal aperture and the basal portion of the colony, besides the margin of the branchial aperture of each zooid; all these unpigmented parts are whitish in colour. Zooids are arranged in the surface layer in a single stratum, the voluminous axial part of the colony is occupied by soft gelatinous tissue which is penetrated by complicatedly running lacunae, in which numerous zoochlorellae are kept by mucus. These algal cells are 13-19 $\mu$ in diameter and cause the green colouration of the inner-side of the colony. In preserved specimens in alcohol, the surface colouration of the colony fades to pale grayish brown, zoochlorella lose their vivid colour; pale yellowish cells easily flow out through the common cloacal aperture. Calcareous spicules are found merely in the superficial layer, they are small, usually $20 \mu$ or thereabout, although larger ones may be up to $30 \mu$ in diameter. Rays are short and very numerous.

Zooid: Average distance between zooids $680 \mu$. Zooids are usually less than $2 \mathrm{~mm}$ in length, thorax being ca. $1.2 \mathrm{~mm}$ and abdomen about $680 \mu$. In general, a thoracic bud and an abdominal one are found at the neck region. Branchial aperture 6-lobed, atrial aperture a huge opening. About eleven elongate stigmata in each of 4 rows; tentacles 16, consisting of 4 large, 4 small and 8 minute ones; dorsal languets are long and slender. Anus opens at the dorso-posterior corner of the thorax. Circumintestinal gland is represented as a granulate tissue embracing the rectum at its middle part. Testicular follicle 1, proximal portion of vas deferens coils ca. 7 times.

Larva: Trunk of larva is nearly roundish in outline, 700-900 $\mu$ in diameter. Three cup-shaped attachment processes are arranged linearly and have each a long peduncle. Three zooids, namely three thoraces and three abdomens, are recognizable in fully developed larvae, of these the dorsal-most zooid is largest and the ventral-most one 
is smallest. Thoraces occupies the dorsal-left side of the trunk and abdomens are situated on the right-ventral side. Two pigment flecks of the sensory organ arranged obliquely. The basal plate of the attachment processes is elongate, both dorsal and ventral ends of this plate are bifurcated and each branch grows large with development. Thus, in fully developed larvae 4 distinct ectodermal ampullae are formed (Figs. 28 \& 29).

Remarks: If the structure of the vas deferens is placed out of the consideration, the present species resembles closely Didemnoides patella GotTSCHALDT and Didemnum pulvinum ToKIoKA $(=D$. gottschaldti TokiokA, 1950) in that it has a huge atrial aperture, well-defined thoracic and abdominal buds and a single testicular follicle and contains zoochlorellae in lacunae and calcareous spicules which consist of numerous short rays. Didemnoides patella and Didemnum pulvinum may be referable to the genus Lissoclinum, because the range of this genus was expanded recently to include a species which has merely a single testicular follicle (Lissoclinum argyllense MiLlaR ). ${ }^{12}$

Furthermore, the boundary between Lissoclinum and Leptoclinum was removed by CARLISLE's discovery ${ }^{2)}$ of delicate spicules in the test of Leptoclinum (=Diplosoma) listerianum. On the other hand, some species of Didemnum are known to be entirely devoid of spicules. The abandonment of the genus Lissoclinum is considered to be reasonable also from the point of the morphology of the embryo. For instance, the larva of Lissoclinum cupuliferum KoTr ${ }^{3)}$ resembles essentially those of species belonging to Leptoclinum.

Now, the larva of the present species resembles closely those of species of Leptoclinum, rather than those of common species of Didemnum. This fact, together with the resemblance of the body appearance and the structure of the test between the present species and Lissoclinum spp., incite me to treat the present species under the genus Leptoclinum. However, the coiling of the proximal portion of the vas deferens in the present species is so distinct that I hesitate to do so. The comprehensive consideration seems to lead me to the idea that Didemnum and Leptoclinum are completely continuous with each other by the medium of Lissoclinum as shown below for instance.

The proximal part of the vas deferens:

(Coils several times) (Curved like a hook) (Neither coiled nor curved)

Didemnum spp. $\longleftarrow$ Didemnoides patella $\left.\longleftarrow \quad \begin{array}{l}\text { Lissoclinum } \\ \text { Leptoclinum }\end{array}\right\}$ spp.

1) Millak, R. H. (1950): Lissoclinum argyllense n. sp., a new ascidian from Scotland. Jour. Mar. Biol. Ass., Vol. 29, pp. 389-392, 1 Fig.

2) CARlisle, D. B. (1953): Presenza di spicole in Diplosoma listerianum (Milne Edwards). Contributo alla sistematica degli Ascidiacea, Didemnidae. Pubbl. Staz. Zool. Napoli, Vol. XXIV, Fasc. 1, pp. 61-67, 1 Fig.

3) Koтt, P. (1952): Observations on compound ascidians of the Plymouth Area, with descriptions of two new species. Jour. Mar. Biol. Ass., Vol. XXXI, pp. 65-83, 3 Figs. 
Structure of larva :

(No budding occurs before the settlement)

Didemnum spp.

$\left\{\begin{array}{l}\text { Lissoclinum argyllense } \\ \text { (See MILLAR 1950) }\end{array}\right.$

(Budding occurs before the settlement)

Lissoclinum cupuliferum

(See KoTT 1952)

Leptoclinum spp.

Number of testicular follicles:

(Usually 1 or 2) (Usually 2, 1 or several

(Usually 2 , rarely 1 ?) in some forms)

Didemnum (Didemnum) spp.—Lissoclinum spp._LLeptoclinum spp.

And the present species can be considered to play also a rôle of an intermediate form between Didemnum and Leptoclinum, because it has the coiled vas deferens and at the same time it produces larvae in which the budding occurs before the settlement. Thus, Didemnum, Lissoclinum and Leptoclinum are probably united into a single genus, Didemnum. But, at present, I wish to restrain a rapid alternation of names and keep the distinction between Didemnum and Leptoclinum on the basis of the far difference in the coiling degree of vas deferens between the two genera. Lissoclinum should be treated as a subgenus of Leptoclinum on the basis of the far difference in the degree of the development of calcareous spicules, and to this subgenus belong Didemnoides patella and Didemnum pulvinum, both treated in my previous papers under Didemnum (Didemnum). The existence of zoochlorellae in lacunae seems to be insignificant phylogenetically.

\section{Eudistoma viridis n. sp.}

(Pl. IV, Figs. 1-5)

Many colonies attached to the debris of reef corals in the canal of Geruherugaeru. They assume usually small roundish masses, about $10 \mathrm{~mm} \times 10 \mathrm{~mm}$ in extent and $7-8 \mathrm{~mm}$ in height; although larger ones attain to the size $25 \mathrm{~mm} \times 27 \mathrm{~mm}$ or $13 \mathrm{~mm} \times 37 \mathrm{~mm}$ and to the height about $13 \mathrm{~mm}$. The basal portion of the colony is generally narrowed considerably. Test soft gelatinous and translucent, the surface is free from any foreign matters. In life, the test is coloured pale greenish and through it the distinct colouration of zooids is seen clearly:-(Fig. 2) endostyle, the neighbourhood of dorsal ganglion, peripharyngeal bands, margins of both branchial and atrial apertures are coloured bluish green, besides a fleck of the same colour is found on each side of the atrial aperture; the alimentary organ orange brown. This colouration is changed to greenish gray or to dark greenish black in preservation in alcohol.

Zooid: Up to ca. $5 \mathrm{~mm}$ in length, abdomen is longer than thorax in preserved specimens. A vascular prominence is issued from the posterior end of the abdomen and in strongly contracted zooids, it assumes the appearance as if it were the postabdomen. Both apertures 6-lobed. The anterior part of the thorax in front of the peripharyngeal band retains the pigmentation in a preserved state and the abdomen 
is also coloured faintly, while the remaining part of the thorax is quite transparent. About 25 elongate stigmata in each of three rows; ca. 15 stout tentacles, comprising large and small ones; dorsal languets are displaced to the left side. Anus is situated on the level of 2nd transverse vessel, two-lobed and smoothly margined. Stomach at nearly the middle of the abdomen, it is roughly globular, smoothly walled and coloured orange. Hind-stomach and mid-intestinal region very distinct. The rectum begins at the posterior end of the intestinal loop, its proximal portion is thickened, but not formed into any coecum. Gonads cover the posterior part of the intestinal loop on the left side, testis consists of numerous botryoid follicles. The incubatory chamber is marked by the pigmentation near the anus on the right side, only an egg is found there in examined zooids (Pl. IV, Fig. 4, inc. ch.). As zooids are somewhat large as compared with the colony, the latter comprises only a small number of zooids situated with their ventral sides towards periphery.

Remarks: The present new species resembles closely Polycitor glaucus SLuiter from the Siboga Area, but the latter has much fewer stigmata in each stigmatal row, only $8-10$. These numbers are less than a half of that in the present new species.

\section{Eudistoma rigida $\mathrm{n}$. sp.}

(Pl. V, Figs. 6-10)

One encrusting colony from the reef of Gadaraku. It is very hard and $40 \mathrm{~mm}$ $\times 100 \mathrm{~mm}$ in extent and ca. $10 \mathrm{~mm}$ in thickness, some thickened massive parts being up to $30 \mathrm{~mm}$. The colouration in life is dark greenish with a yellowish green tint at some places of the colony, but this colouration changes uniformly to bluish black in preservation in formalin.

Test: The test is very compact and hard in consistency and carries no foreign matter on the surface or within it, except in the thickened places where some faecal pellets are embedded in the test. The surface is nearly even excepting a few wide but low swellings arranged irregularly, besides a minute promninence above each zooid.

Zooid: Zooids may be up to $6 \mathrm{~mm}$ in length and yellowish brown in colour when alive, system quite indistinct. Thorax rather short, about $1 / 4$ of the whole body length in a preserved state. Both apertures 6-lobed, the atrial siphon considerably thick. Probably fourteen to fifteen elongate stigmata in each of three rows: tentacles 10-12, excluding minute ones; ciliated groove is an oval orifice; dorsal languets are slightly displaced to the left side. Anus is situated on the level of the 2nd transverse vessel and bilobed. Stomach is situated on the level of about a third of the length of the abdomen from the posterior end and roughly reniform in profile (Fig. 10) and smoothly walled. Mid-intestinal region distinct and passes to the rectum at the posterior end of the intestinal loop; the proximal part of the rectum is swollen but not forming any coecum. The circum-intestinal gland assumes several tubular tissues 
surrounding the rectum on the level of the hind-stomach (fig. 9). Testis consists of many follicles filling up the intestinal loop posterior to the stomach, two ova are found near the centre of the testis in examined zooids. A thin vascular prolongation is issued from the posterior end of the abdomen.

\section{Distaplia mikropnoa (SLUITER), 1909}

(P1. V, Figs. 11-16 ; Text-fig. 2)

Ten massive colonies in the material, larger ones are $15 \mathrm{~mm} \times 25 \mathrm{~mm}, 13 \mathrm{~mm} \times$ $40 \mathrm{~mm}$ or $20 \mathrm{~mm} \times 35 \mathrm{~mm}$ in extent and $8-15 \mathrm{~mm}$ in height; the basal portion is narrowed in some colonies. The colouration in life is yellowish orange to brownish orange with darker pigmentation at some parts and dotted with whitish pigment spots which are arranged usually as to divide the surface of the colony into several areas. In preservation in alcohol, it is changed to yellowish brown. Test gelatinous and translucent, but very tough in consistency, being strongly adherent to zooids, of which the abdomen and the postabdomen can hardly be taken out of the test without any injury. The surface is free from foreign matters, several round common cloacal apertures are found here and there; system indistinct. The common cloacal aperture is fringed with a number of lobules which are nothing else than distal ends of atrial languets of zooids and marked with white colouration (Fig. 14). The margin of the branchial aperture is sometime provided with a whitish lobe which is probably the prolongation of one of the branchial lobes of respective zooids (Fig. 13).

Zooid: Zooid ca. $4 \mathrm{~mm}$ in length, the thorax being about a half of the abdomen in length and the postabdomen is nearly as long as the thorax in a preserved state. The proximal portion of the postabdomen is elongated to a thin peduncle of a considerable length. The mantle coating the whole zooid is richly dotted with corpuscles. Branchial aperture 6-lobed; atrial aperture is a huge opening, situated asymmetrically and with a conspicuous atrial languet ending in a simple tip. About eighteen stigmata in each of 4 rows, parastigmatic vessels absent. No papilla on the transverse vessels. Tentacles about a dozen, dorsal languets distinct. Anus bilobed and situated on the level of the 3rd transverse vessel. Stomach is situated near the middle of the abdomen, elliptical in outline and with about 10 fine longitudinal plications on each side; hind-stomach distinct; mid-intestinal region is inconspicuously discernible. Rectum begins slightly in front of the posterior end of the intestinal loop on the first branch. Gonads in the distal swollen part of the postabdomen, one ova situated distally and testicular follicles, for instance 16 in an examined zooid, located proximally.

Larva: Many large embryos are found in the colony, although no incubatory pouch is discriminated distinctly. The trunk of a large larva is $1240 \mu$ in length, width/length being 0.74 . Three cup-shaped attachment processes are arranged in a triangle, each with a swollen base. Larval test is conspicuously granulated with 
abundant test cells. The body organization of a zooid is nearly completed in welldeveloped larvae; ca. 7 longitudinal muscles are found on each side of the thorax, ca. 15 stigmata are counted in each stigmatal row and fine longitudinal plications can already be discriminated clearly on the stomach (Text-fig. 2).

Remarks: The present species is one of the most perplexing forms in the material. The appearance of the postabdmen resembles that of Polyclinum, but the absence of the papillae on the transverse vessels of the branchial sac, simply stretched intestinal loop and the wide atrial aperture deny the affinity to that genus. Stretched intestinal loop, with considerably well-defined stomach plicated longitudinally, shows some resemblance to Aplidium. However, the huge atrial opening and the structure of the larva contradict this consideration. General body appearance, with characteristical arrangement of ovary and testis in the saccular postabdomen, and the organization

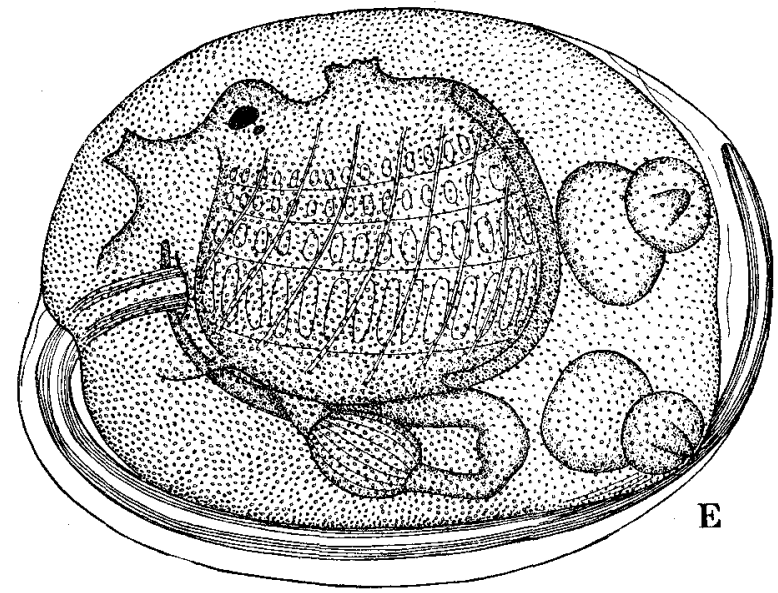

Fig. 2. Distaplia mikropnoa (SLuITER).

Embryo from right side, $\times 57$. One of the three attachment processes, situated on the left side, is omitted in the figure.

of the larva are nothing else than good indicators for the genus Distaplia, although the relative largeness of the abdomen is too much for this genus and the parastig. matic vessel is quite absent. Especially, the last point is very important; the definition of the genus must be expanded to include forms without parastigmatic vessels in order to embrace the present species in the genus. Superficially the present species resembles closely Distaplia stylifera (Kowalevsky) in the appearance of the zooid, but the former differs from the latter distinctly in the absence of the parastigmatic vessels and the extraordinary wideness of the atrial aperture. Most probably, the present form may be identical with Polyclinum mikropnous SLUITER from the Siboga area. The differences found between these two forms, for instance in the size of the atrial aperture and in the appearance of the genital organs, may be attributable to the differences in the state of contraction or in the degree of maturity. 


\title{
8. Polycarpa aurata (QuOY et GAIMARD), 1834
}

\author{
(P1. VI, Figs. 17-20; Text-fig. 3)
}

Polycarpa sulcata-HERdMAN (1882): Challenger Report, Vol. 6, pp. 179-180, Pl. 23 figs. 9-13. v. DRASche (1884): Denkschr. der mathem.-naturw. Gl., Bd. 48, pp. 379-380, Pl. VI fig. 12, P1. VII figs. $1,2,2$ a.

Traustedt (1885): Vidensk. Meddel. Nat, For. Kjobenhavn, ann. 1884, p. 48.

Styela psoloessa--Sluiter (1890): Natuurk. Tijdschr. Ned.-Ind., Bd. 50, p. 339.

Styela (Polycarpa) pneumonodes-StuITER (1895) : Denkschr. med. naturwiss. G1. Jena, Bd. 2. p. 179, P1. 10 figs. 1-3.

Polycarpa aurata var. plana-HERDMAN (1899): Descriptive Catalogue of the Tunicata in the Australian Museum, pp. 51-53, Pl. Cyn. xx figs. 1-5.

Polycarpa aurata-StuTTER (1904): Siboga-Exped., Monogr. 56 a, pp. 57-58.

Herdm:n (1906): Ceylon Pearl Oyster Fish., Suppl. Rep., No. 39, p. 318, Pl. 5 figs. 1-6.

HARTMEyer (1919): Kungl. Sv. Vet. Akał. Handl., Bd. 60, No. 4, p. 40, Pl. I figs. 17-18. Hastings (1931): Great Barrier Reef Exped,, Sci. Rep., Vol. IV, No. 3, p. 74.

Polycarpa pedunculata-Pizon (1908): Rev. Suisse Zool., Vol. 16, p. 216, P1. 12 figs. 21-24.

Pandocia aurata-VAN Name (1918): U. S. Nat. Mus. Bull. 100, Vol. I, Pt. 2, pp. 94-96, Figs. 4748, PI. 25 figs. 5-6.

Polycarpa aurata f. clavata - Kотт (1952): Austral. Jnl. Mar. Fresh. Res., Vol. 3, No. 3, pp. 236-237, Fig. 46.

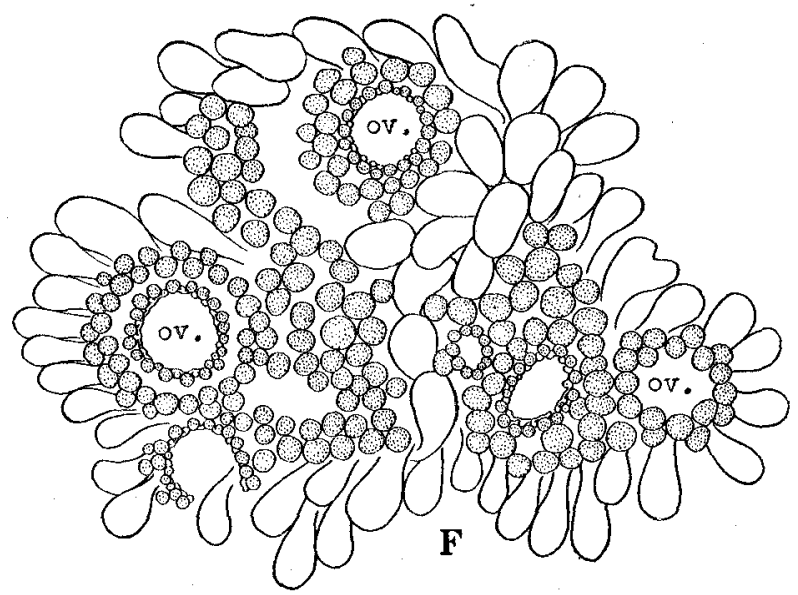

Fig. 3. Polycarpa aurata (QUOY et GAIMARD).

A gonad from the side of the attachment, enlarged. ov.-ovary.

A $80 \mathrm{~mm}$ long specimen collected at Ponape Island. Width of the body $35 \mathrm{~mm}$ at the middle and $40 \mathrm{~mm}$ near the posterior end by which the animal attaches to the substratum. The body is considerably compressed laterally, about $10 \mathrm{~mm}$ except in the posterior portion where it reaches $17 \mathrm{~mm}$. Branchial aperture terminal, the atrial on the dorsal edge near the middle; both apertures 4-lobed. Test soft leathery, but tough in consistency; yellowish white in preservation in alcohol-formalin. The surface is smooth, free from any foreign matters and marked with a few characteristical 
longitudinal grooves. Thickness of test $1 \mathrm{~mm}$, up to $2 \mathrm{~mm}$ in the posterior thickened portion; the inner surface is whitish and with pearly glistening. Mantle thin and yellowish brown in colour. Endocarps small, atrial velum is not well-developed.

Branchial sac: Inner longitudinal vessels are arranged as :-

$\begin{array}{llllllllllll}\text { Left } & \text { D. } & 5 & (19) & 6 & (23) & 6 & (22) & 6 & (19) & 7 & \text { V. } \\ \text { Right } & \text { D. } & 6 & (23) & 5 & (23) & 5 & (22) & 5 & (17) & 6 & \text { V. }\end{array}$

Three thinner transverse vessels between each pair of thicker ones, parastigmatic vessels are found sparsely in the posterior portion of the sac. Five to nine stigmata in a mesh. Fifteen large tentacles alternate regularly with smaller ones of the same number. Dorsal tubercle large, $3.5 \mathrm{~mm}$ in length; ciliated groove divided into 167 short slits (Fig. 20).

Alimentary system: Intestinal loop occupies a small dorso-posterior part of the left side and coloured grayish brown. Oesophagus rather long; stomach narrow and elongate, occupies about $2 / 3$ of the ventral branch of the loop and superficially with smooth surface, through which ca. 8 longitudinal plications of the inner wall are seen faintly. Three minute endocarps in the loop. The axis of the second intestinal loop passes through the cardiac portion of the stomach, anus fringed with ca. 20 lobules.

Gonad: Forty-eight gonads are scattered on the left side and 51 gonads on the right side. They are wholly burried in the mantle. However, the situation of respective gonads is indicated by ducts and irregularly arranged attachment points of endocarps and mesenterial filaments (Text-fig. 3 ). The gonad itself is very irregular in outline, larger ones may reach $5 \mathrm{~mm}$ in diameter and contains several ovaries which are indicated clearly by circular arrangement of minute ova (ov. in Text-fig. 3).

\section{Pyura sp.}

(P1. VI, Figs. 21-23; Text-fig. 4)

A $18 \mathrm{~mm}$ long $\times 10 \mathrm{~mm}$ wide specimen from the reef of Gadaraku. The body is roughly elliptical in outline and erected, being attached by the posterior end. The branchial aperture terminal and the atrial on the level of a third of the body length from the anterior end; both apertures 4-lobed. Test yellowish white in colour and not thick, but very tough in consistency. The surface carries many sand grains and wrinkled considerably. Mantle with well-developed musculature, the anterior half, including both siphons nearly as long as a third of the body length, is coloured red and the posterior half is yellowish white. Atrial velum well developed, no endocarp is detectable.

Branchial sac: As the left half of the mantle body is injured severely, I can give only the following notes about the branchial sac. Probably six branchial folds 
and a rudimentary seventh (the ventral-most) one. About 10 inner longitudinal vessels on each fold and ca. 2 on respective intermediate areas in the central part of the sac. Transverse vessels arranged in the order of large-small-medium-small-large. Three to five stigmata in a mesh. Tentacles ca. 20, including large and small ones; branches in 2 orders, those of the 1st order are rather slender. Ciliated groove of the shape of lying $\mathrm{S}$; dorsal lamina represents a series of finger-shaped languets.

Alimentary system: Mutilated so much that I can not offer here any detail, excepting that the liver is dark greenish in colour and consists of many elongate mammilary lobules (fig. 23).

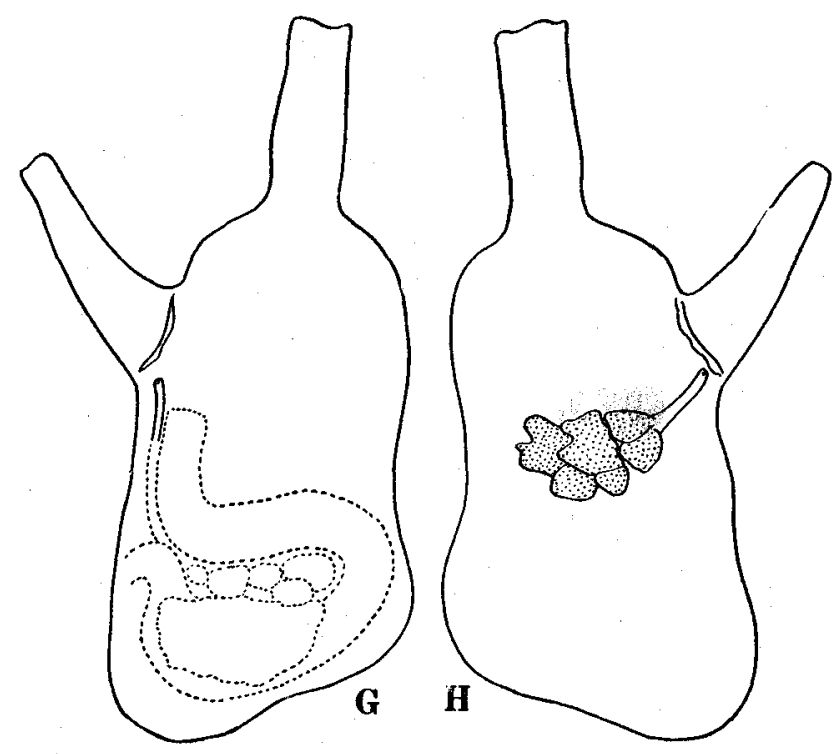

Fig. 4. Pyura sp.

G-Right half of mantle body, from inside; H-Left half of mantle body, from inside.

Gonad: Right gonad is very short and consists of 6 genital capsules. The left one is torn out, but it was probably located in the intestinal loop as in other common pyurids, because the distal end of the genital duct of the left gonad is opened near the posterior base of the atrial siphon.

Remarks: It is sure that the present specimen belongs to the genus Pyura, and it is very possible that the specimen represents a new form characterized by short gonad. However, I restrain here to give new name to the specimen, because it is injured too much to be used as a type-specimen. 


\section{EXPLANATION OF PLATES I-VI}

\section{Plate I}

Figs. 1-5. Aplidium lobatum Savigny.

1 ......Colonies attached to a piece of sea-weeds, slightly enlarged.

2 ......A colony, enlarged.

3 ......Zooid from left side, magnified.

4, 5 ...Atrial languets of different shapes, magnified.

Figs. 6-9. Didemnum (Didemnum) moseleyi (Herdman).

$6 \quad$......Calcareous spicules, $\times 440$.

$7 \quad$......Zooid from left side, $\times 110$.

8, 9 ...Circum-intestinal glands in different appearances, magnified.

\section{Píate II}

Figs. 10-17. Didemnum (Didemnum) candidum Savigny.

10,11 ..Calcareous spicules, $\times 440$.

12 .....A part of the surface of a colony, $\times 15$.

13 ......Smaller zooid from left side, $\times 73$.

14 ......Abdomen of the same zooid from right side, $\times 73$.

15 .......Larger zooid from left side, $\times 73$.

16 ......Abdomen of the same zooid from right side, $\times 73$.

17 ......Embryo from right side, $\times 73$.

\section{Plate III}

Figs. 18-29. Didemnum (Didemnum) ternatanum (GottschaldT).

18 ......A colony, enlarged.

19 ...... Optical section of colony.

20 ......Calcareous spicules, $\times \mathbf{1 2 0 0}$.

21 ......Zoochlorellae, $\times \mathbf{1 2 0 0}$.

22 ....... Zooid from left side, $\times 47$.

23 ......Abdomen of the same zooid from right side, $\times 73$.

24 ......Tentacles, magnified.

25 ......Young embryo, $\times 47$.

26 ......Well-developed embryo, $\times 57$.

27 ......An attachment process, magnified.

28,29 ... Basal plates of attachment processes in different stages of development, magnified. 
Plate IV

Figs. 1-5. Eudistoma viridis n. sp.

1 .....A colony, enlarged.

2 ......Apical view of a zooid, magnified.

3 ......Zooid from left side, magnified.

4 ......Abdomen of the same zooid from right side, magnified. inc. ch....incubatory chamber.

5 ......Contracted zooid, $\times 23$.

\section{Plate V}

Figs. 6-10. Eudistoma rigida n. sp.

6 .......Colony, $\times 0.4$.

$7,8 \ldots .$. Zooid, magnified.

9 ......Abdomen, gonads being taken off ; magnified.

10 ......Stomach in profile, magnified.

Figs. 11-16. Distaplia mikropnoa (SluITER).

11 ......Upper side of a colony, slightly enlarged.

12 ......Lateral side of the same colony.

13 ......Branchial aperture with a lobule, magnified.

14 ......A part of the common cloacal aperture, magnified.

$15 \ldots . .13 \mathrm{~mm}$ long small colony.

16 ......Zooid from right side, $\times 23$.

\section{Plate Vi}

Figs. 17-20. Polycarpa aurata (Quoy et GaImard).

$17 \ldots . .80 \mathrm{~mm}$ long individual from left side.

18 ......Left half of mantle body, from inside.

19 ......Right half of mantle body, from inside.

20 ......Dorsal tubercle, enlarged.

Figs. 21-23. Pyura sp.

$21 \ldots . .18 \mathrm{~mm}$ long individual from left side.

22 ......Ciliated groove, magnified.

23 ......A part of liver, magnified. 
Publ. Seto Mar. Biol. Lab., V, 1 (1955)

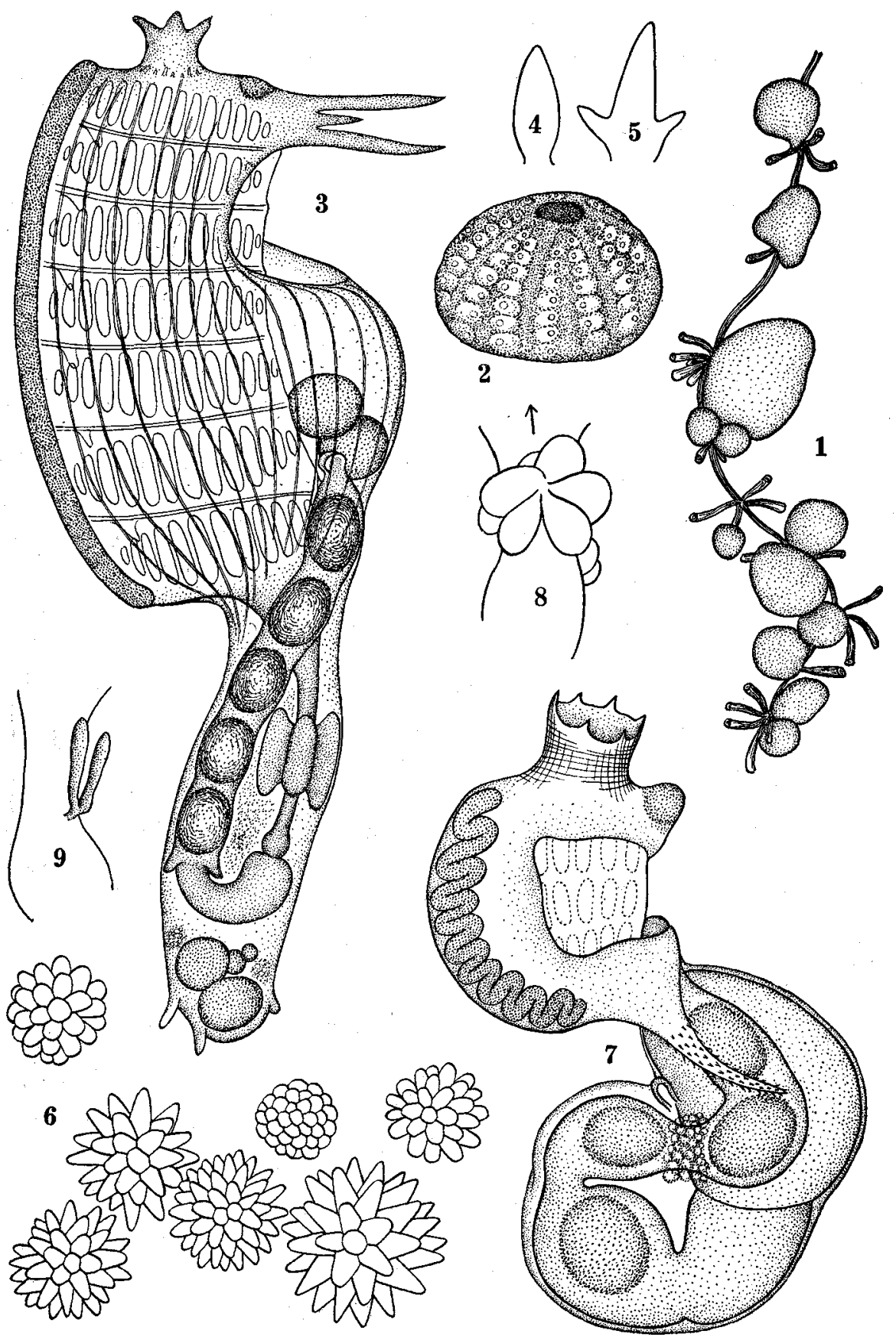

T. Tokioka: Ascidians from the Palao Islands, II. 
Publ. Seto Mar. Biol. Lab., V, 1 (1955)

PLATE II

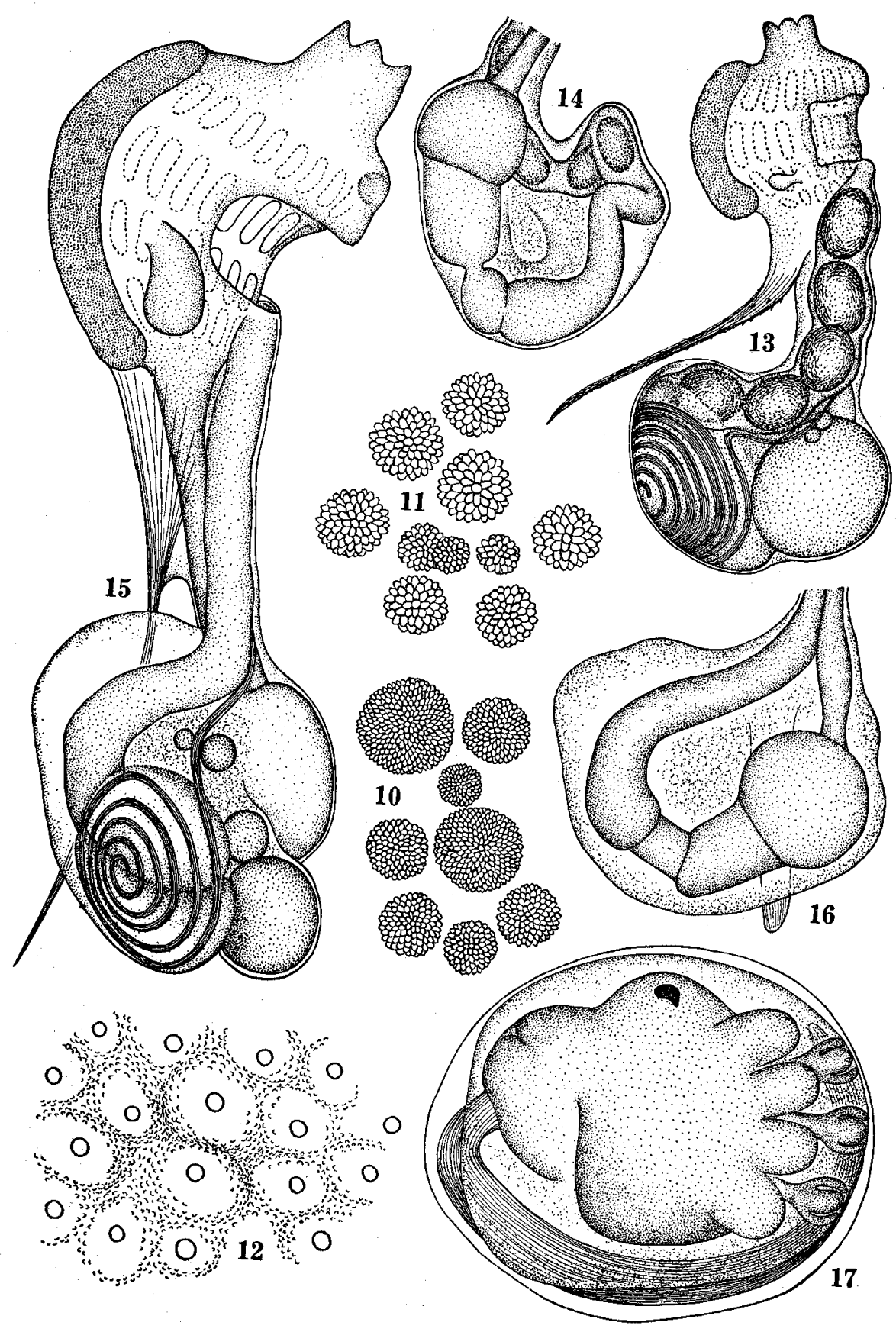

T. Tokioka: Ascidians from the Palao Islands, II. 


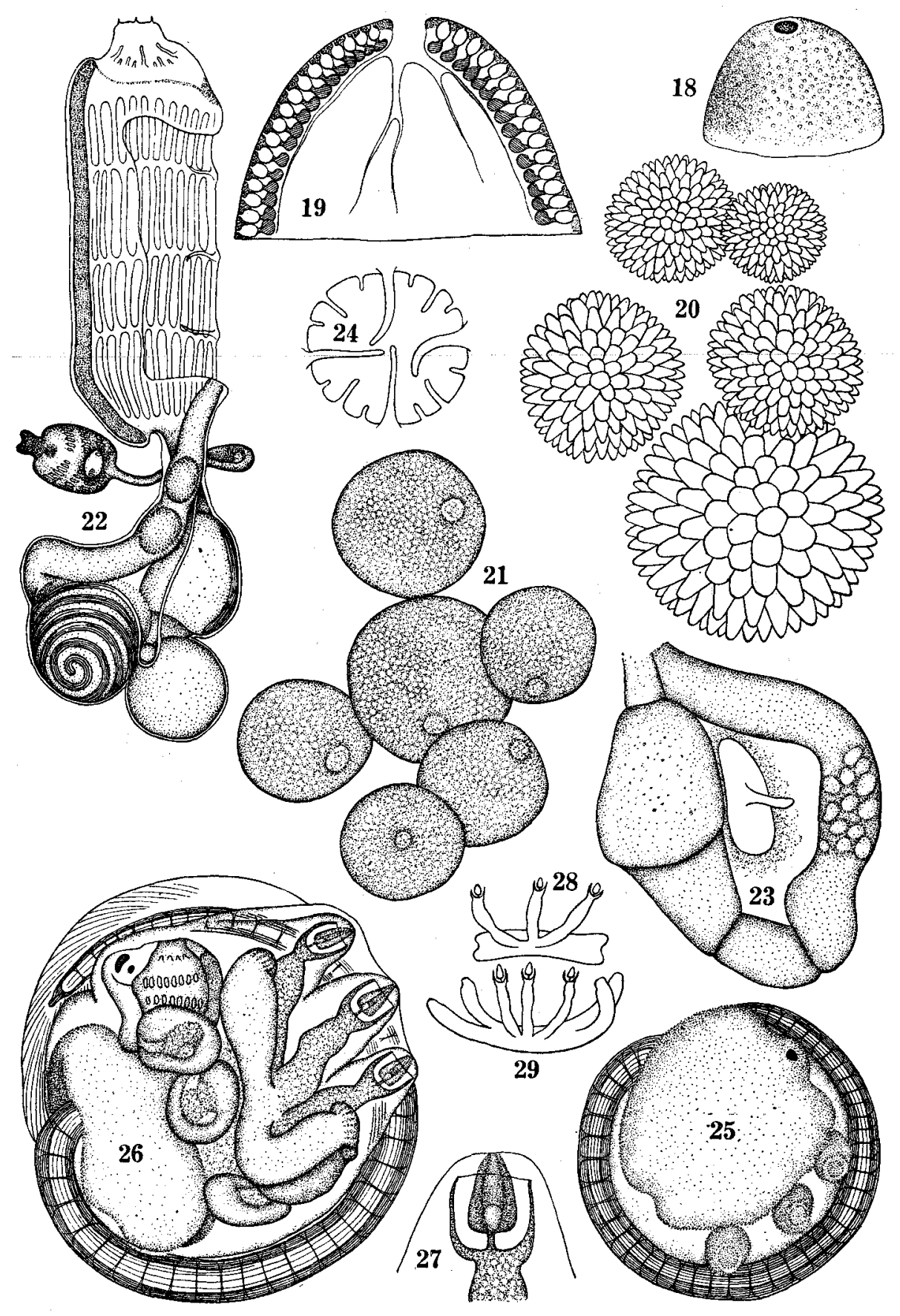

T. Tokioka: Ascidians from the Palao Islands, II. 
Publ. Seto Mar. Biol. Lab., V, 1 (1955)

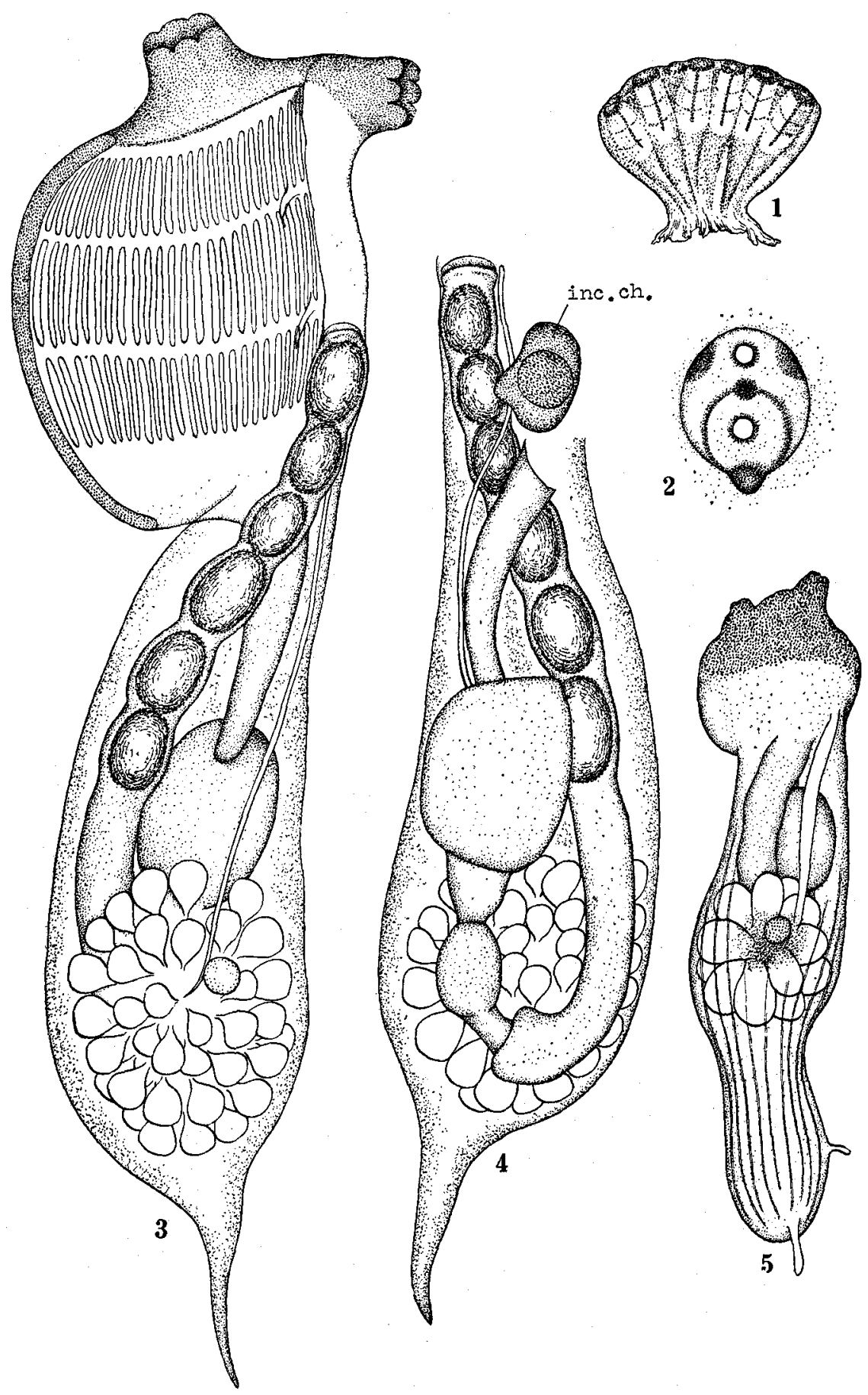

T. TOKIOKa: Ascidians from the Palao Islands, II. 
Publ. Seto Mar. Biol. Lab., V, 1 (1955) PLATE V

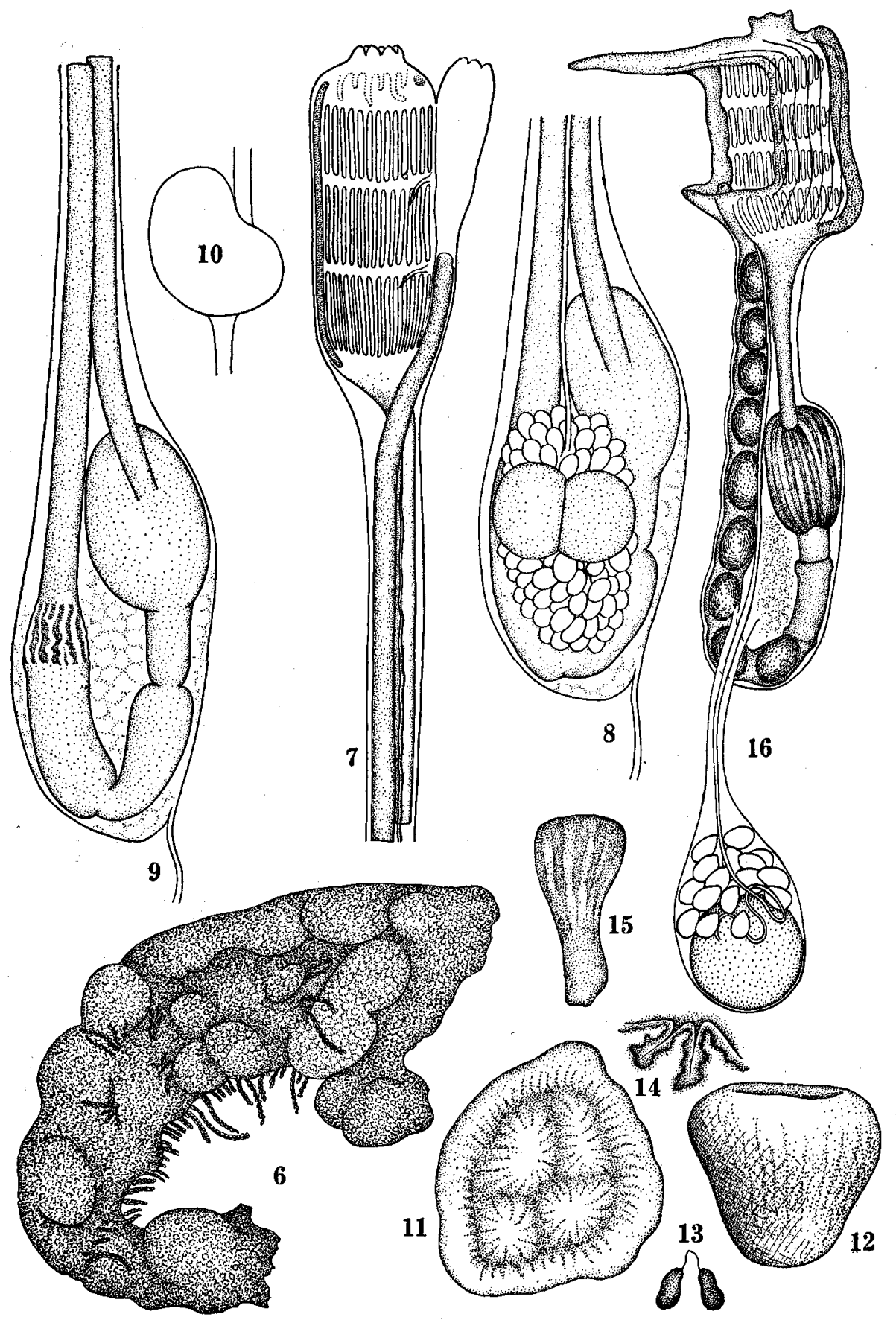

T. Tokioka: Ascidians from the Palao Islands, II. 
Publ. Seto Mar. Biol. Lab., V, 1 (1955)

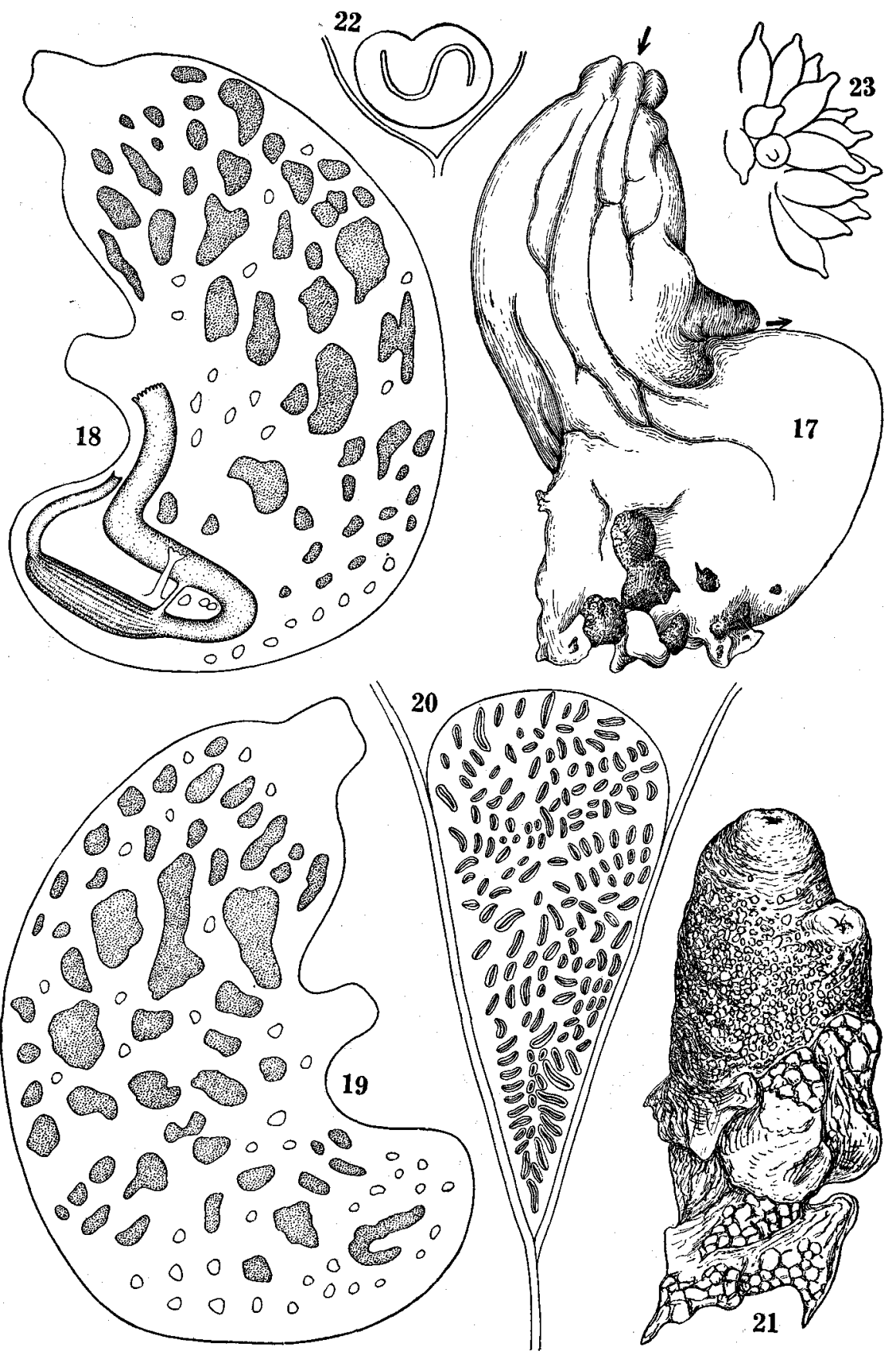

T. Tokioka: Ascidians from the Palao Islands, II. 